\title{
The fiscal benefits of stringent climate change mitigation: an overview
}

\author{
$\underline{\text { Jan Siegmeier }}^{1}{ }^{2}$, Linus Mattauch ${ }^{3}{ }^{4}$, Max Franks $^{5}$, \\ David Klenert ${ }^{245}$, Anselm Schultes ${ }^{25}$, Ottmar Edenhofer $^{245}$
}

October 25, 2017

\begin{abstract}
The Paris Agreement's very ambitious mitigation goals, notably to "pursue efforts" to limit warming to $1.5^{\circ} \mathrm{C}$, imply that climate policy will remain a national affair for some time. One key obstacle to very ambitious national mitigation is that some policymakers perceive this to be in competition with major goals of fiscal policy, such as public investment or debt reduction. However, climate policy may actually contribute to these other objectives. Importantly, many fiscal implications of substantial carbon prices, which are essential for stringent mitigation targets such as the $1.5^{\circ} \mathrm{C}$ goal, have long been neglected by economic analyses of climate change mitigation.

We systematically review recent contributions on interactions between climate policy and public finance, which include many topics beyond the classic 'double dividend' of environmental tax swaps. We can thus identify new conclusions about climate policy designs that may overcome fiscal objections and research gaps. We find that national climate policy often aligns with other objectives, provided that climate- and fiscal policies are integrated well.

A first class of interactions concerns public revenue-raising: carbon pricing can replace distortionary taxes and alleviate international tax competition; climate policy also changes asset values, which impacts the base of non-climate taxes and boosts productive investment. Second, they concern public spending, which needs to be restructured as a part of climate policy, while carbon

${ }^{1}$ Corresponding author. Mercator Research Institute on Global Commons and Climate Change, Torgauer Str.

12-15, 10829 Berlin, Germany. Email: siegmeier@mcc-berlin.net. Phone: 0049-(0)30-3385537-220.

2 Technical University of Berlin, Straße des 17. Juni 135, 10623 Berlin, Germany.

${ }^{3}$ Environmental Change Institute and Institute for New Economic Thinking at the Oxford Martin School, School of Geography and the Environment, University of Oxford, South Parks Road, Oxford OX1 3QY, United Kingdom.

${ }^{4}$ Mercator Research Institute on Global Commons and Climate Change, Torgauer Str. 12-15, 10829 Berlin, Germany.

5 Potsdam Institute for Climate Impact Research, Telegraphenberg A 31, 14473 Potsdam, Germany.
\end{abstract}


pricing revenues may be recycled for public investment. Third, distributional impacts of climate policies include changes to household expenditures, to asset values and to employment; balancing them often requires fiscal policies.

Our findings underline that jointly considering climate and fiscal policy can help to make substantial mitigation politically feasible.

\section{Key policy insights}

- Climate policy, even under a very ambitious $1.5^{\circ} \mathrm{C}$ target, may substantially contribute to fiscal objectives, interact with fiscal policies, and lower mitigation costs.

- Mutual effects concern taxation, aggregate investment, public budgets, infrastructure, and fiscal instruments with distributional effects.

- Better integrating climate and fiscal policies increases efficiency and supports political feasibility of very ambitious mitigation.

- This requires a common understanding of policy makers and academics on the most relevant interactions, based on more exchange and empirical research.

JEL classification: B41, H21, H23, H54, H60, Q54

Keywords: carbon pricing, stringent mitigation, tax / taxation, public spending, distributional effects, policy interactions / integration

\section{Acknowledgements}

We thank three anonymous reviewers, the guest editors and the managing editor for their helpful suggestions. Matthias Roesti provided excellent research assistance. We further thank Christopher Bren d'Amour, Patrick Doupé, Christian Flachsland, Beatriz Gaitan, Cameron Hepburn, Brigitte Knopf, Nicolas Koch, Gregor Schwerhoff, Christoph von Stechow and seminar participants at the Mercator Research Institute of Global Commons and Climate Change for useful comments. We thank Gunnar Luderer for advice on using Integrated Assessment Model results. Linus Mattauch thanks the German Academic Scholarship Foundation for financial support. His research was also supported by a postdoctoral fellowship of the German Academic Exchange Service (DAAD). 


\section{Introduction}

In the 2015 Paris Agreement, nation states agreed to not only limit temperature increase to "well below" $2^{\circ} \mathrm{C}$ above pre-industrial levels, but to "pursue efforts" to limit warming to $1.5^{\circ} \mathrm{C}$ (Paris Agreement, Article 2.1(a)). To meet these stringent collective mitigation goals, the Paris Agreement relies on voluntary, non-binding 'nationally determined contributions', so nation states will decide independently about the ambition and implementation of their climate targets for the foreseeable future. However, at the national level, mitigation policies are often seen as being in competition with other major goals of fiscal policy, while potential beneficial interactions between these policy areas are neglected. This is a significant problem, given that strong mitigation policy action is indispensible, if the international community is to keep open the possibility of meeting the $1.5^{\circ} \mathrm{C}$ goal.

For example, imagine a policy-maker who recognizes that a necessary condition for a fast and large-scale decarbonization of her country's economy is a stiff price on carbon. However, she associates high carbon prices with adverse effects on jobs, competitiveness and growth. At the same time, other economic policy questions occupy her, such as how to fix the country's broken infrastructure. To adequately deal with these perceived trade-offs, she requires a better understanding of the interactions between carbon pricing and other fiscal policy objectives and needs to know which of them can be beneficial. This is the case as high carbon prices also raise sizable public revenues that affect the broader tax system and have implications for public spending and distributional considerations. Despite their political relevance, climate change economics has long neglected most of these interactions and focused on inefficiencies directly related to mitigation. Vice versa, public finance typically ignores constraints and opportunities of future decarbonization.

In this article, we systematically review recent contributions on interactions between climate change mitigation and public finance. These new contributions treat a much broader set of topics than the previous literature, while being far from exhaustive in their analysis to date. This permits us to derive some new conclusions about how climate policy must be designed to align with fiscal policy objectives, and to identify research gaps. We specifically focus on links between the climate externality and fiscal objectives that are not related to mitigation. Interactions can be grouped under the topics of public revenue-raising, public spending and distribution. For each topic, we start by identifying mutual effects on climate- and fiscal objectives when climate- and fiscal policies are designed independently; then, we collect insights on how policies can be adjusted to maximize beneficial interactions, minimize costs and avoid obstacles to implementation; finally, we identify 
implications for very stringent mitigation policies and urgent research questions. Furthermore, we discuss potential obstacles to a better integration of climate- and fiscal policies.

We find, first, that there are interactions of substantial magnitude if mitigation is ambitious. Some effects of climate policy are likely to directly contribute to fiscal objectives and welfare, for example when carbon pricing improves investment signals and raises public funds. In other cases, if climateand fiscal policies are designed separately, the effectiveness of climate policy may be severely reduced, for example when the stock of public infrastructure is not adjusted accordingly. Second, such problems can often be avoided by integrating climate- and fiscal policies, and positive contributions of climate policy to other objectives can be considerably strengthened. Third, this much-needed further integration hinges on obtaining a common understanding on which interactions are the most relevant by policy makers and academics of both fields. This requires an active exchange and more empirical research.

Specifically, the first group of interactions that we identify concerns public revenue-raising: carbon pricing impacts national tax systems and international tax competition. This is important because the revenues raised even for a $2^{\circ} \mathrm{C}$ target may already amount to $14 \%$ of total tax revenue in the USA (see Section 2.1). Further, climate policy affects future revenues from certain capital goods, land and natural resources and thus the values of these assets, which in turn influences the base of non-climate taxes and redirects investments, for example from fossil resource stocks towards capital. Second, interactions concern public spending, which needs to be restructured as a part of climate policy, while carbon pricing revenues may be recycled for productive public investment.

Third, carbon pricing affects the distribution of resources across groups in a society via changes to household expenditures on food, energy, transport and housing, to asset values and to employment; this may have to be balanced by other fiscal policies.

The body of literature on climate-fiscal interactions is relatively small (with one exception): Climate change economics mostly focuses on directly mitigation-related sectors, inefficiencies and policies. Public economics on the other hand has considered environmental tax swaps (i.e. substituting environmental for existing taxes) in great detail, but largely neglects other interactions.

More precisely, in climate change economics, studies of optimal mitigation targets and pathways commonly use 'integrated assessment models' (Weyant et al., 1996) with high detail regarding physical climate change and technologies in emission-relevant sectors (Nordhaus and Boyer, 2000; Luderer et al., 2012; Clarke et al., 2014). In contrast, other welfare-relevant aspects of the socio-economic system, such as infrastructure and health issues not directly related to climate damages, or the distribution of income and wealth, are often modeled crudely or not at all (exceptions include Thompson et al. (2014) and Rausch et al. (2010, 2011)). 
Specific climate policy instruments, such as carbon pricing, emission standards or R\&D support for low-carbon technology, are commonly analyzed together with another non-climate inefficiency. However, the latter is usually directly related to emission-relevant sectors, such as imperfect coverage of carbon pricing schemes, or market failures in the energy sector linked to innovation or imperfect competition (Sorrell and Sijm, 2003; Fischer and Newell, 2008; Gillingham et al., 2009; Kalkuhl et al., 2011; Mattauch et al., 2015). There is one prominent exception with a fiscal non-climate externality, namely 'double dividends' of environmental tax swaps when no non-distortionary instruments are available for public revenue raising (Goulder, 2013, see Section 2.1).

Previous reviews of the fiscal dimensions of climate policy (Poterba, 1993; Jones et al., 2013; de Mooij et al., 2012) cover these topics, in particular the double dividend, and the potential of climate policy to finance public spending on mitigation and adaptation (including international transfers). We take the next step by reviewing recent research that extends the idea of the double dividend to other combinations of climate policies with fiscal inefficiencies in Section 2. Section 3 discusses obstacles to policy integration. Section 4 concludes.

\section{The fiscal benefits of stringent climate change mitigation}

The literature on beneficial interactions between mitigation policies and other public policy objectives and instruments can be structured as follows: Section 2.1 focuses on the revenue side of the public budget. Section 2.2 discusses the spending side. Section 2.3 considers distributional impacts of climate policy, including the redistributive recycling of carbon pricing revenues by various fiscal instruments.

\subsection{Carbon pricing, rents and public revenues}

Climate policies may directly create revenues, for instance through carbon pricing, or by changing the bases of other taxes such as capital, labour or land taxes. These fiscal interactions matter since policies in line with ambitious mitigation targets are expected to create relatively large revenues: A naïve back-of-the-envelope calculation shows that a carbon price consistent with the $2^{\circ} \mathrm{C}$ target may raise revenues amounting to $5 \%$ of total tax revenues in the EU, $14 \%$ in the USA, and $11 \%$ in Japan. ${ }^{6}$ Achieving a $1.5^{\circ} \mathrm{C}$ target requires approximately doubling the carbon price compared to a $2^{\circ} \mathrm{C}$ target

\footnotetext{
6 Authors' own calculation, using the mean carbon price in 2020 of US\$(2015) 40 for the $2^{\circ} \mathrm{C}$ target from a model intercomparison (Kriegler et al., 2013; LIMITS consortium, 2013). Total greenhouse gas emissions in 2014 in $\mathrm{GtCO}_{2}(\mathrm{eq})$ were 4.3 in the EU, 6.5 in the US, and 1.3 in Japan. Tax revenues in 2014 are taken from WDI (2016). This of course ignores implementation difficulties of such a comprehensive scheme and behavioural responses. Using more elaborate general-equilibrium models for carbon pricing revenues, as for instance in Edenhofer et al. (2015a), leads to comparable results.
} 
(Rogelj et al., 2015), which increases the relevance of carbon taxation for fiscal policy strongly (see below). ${ }^{7}$

In this section, we begin by reviewing potential interactions when policies are designed independently. The aim of this first step is to establish a common understanding of the interactions between carbon pricing and other fiscal policy objectives. The interactions identified in the literature consist of the reactions of private economic agents to climate and fiscal policies that a national government implements and that are not aligned. Then, we consider adjustments identified by the literature so far that may yield benefits by increasing efficiency and help to overcome obstacles to climate policy implementation. In other words, we begin with the case that finance and environmental ministers do not talk to each other, and then move to suggestions how the two could cooperate. Finally, we summarize the implications for very stringent climate policy and the most important research gaps.

\section{Effects when environmental and finance ministers do not coordinate their policies}

Carbon pricing is generally motivated by its short-term effect on the marginal costs of emissions, and by its long-term effect on investment into low-carbon technologies (Section 2.2). However, climate policy also affects other investments - notably into fossil resources, general producible capital and land - with implications for macroeconomic variables and public revenues:

How investors choose between assets such as producible capital stocks, land, and stocks of non-renewable resources strongly depends on their respective expected returns. Policies that decrease the returns of one asset induce agents to shift investment towards other assets. We expect climate policy to induce such portfolio effects in the following two instances.

First, if carbon pricing reduces the rents from fossil resource stocks, investment may shift towards producible capital. This 'macroeconomic portfolio effect' constitutes a fiscal benefit of carbon pricing: It is an interaction that enhances welfare beyond its environmental benefits if capital was otherwise underaccumulated (Siegmeier et al. (2015), building on Feldstein (1977) and Edenhofer et al. (2015b)). ${ }^{8}$ The basic argument holds independent of uncertainties about the costs of exploration, extraction and substitute technologies, or the size of fossil reserves. In practice, the strength of the effect will mainly depend on implementation details of the carbon price (fully auctioned emission permits may collect more rents than a variable carbon tax), on the amount of fossil assets that are covered, and on their importance in investors' portfolios (Siegmeier et al. (2015); Battiston et al.

7 Carbon pricing revenues in developed countries may not enter the general public budget, but could be 'earmarked' to finance international transfers in support of climate change mitigation in developing countries (see for example Bowen (2011) or Jones et al. (2013)). This would neutralize some interactions in this and following sections that rely on revenue recycling.

8 Under an emission permit scheme, the cap on emissions creates a scarcity that may actually increase the rents of resource owners if they are compensated with free emission permits (Kalkuhl et al., 2013). 
(2017) estimate that private portfolios in the EU and the USA consist of $4-7 \%$ fossil fuels, $1-3 \%$ fuel-price dependent utilities and $21-28 \%$ energy-intensive industries, depending on investor type). Second, very stringent climate policy will affect rents from urban and non-urban land. In contrast to fossil resource stocks, climate policy does not generally collect any additional land rents. However, it may increase the potential revenues from land taxes since very stringent climate policy is likely to increase the scarcity of land and hence also land prices and land rents.

For non-urban land, land-based mitigation efforts such as the large-scale deployment of bioenergy (Creutzig et al., 2015b), carbon-capture-and-storage (CCS) or changes in land management practices (Clarke et al., 2014; Hertel, 2011) may increasethe level and change the distribution of land rents, which could distort aggregate capital accumulation and lead to reduced growth. ${ }^{9}$ For urban land, climate policy is likely to increase the overall value of land rents: most cities aiming for carbon-neutrality would have to become denser in many areas to support low-carbon modes of transport (Sims et al., 2014; Seto et al., 2014) and each unit of land within the city boundaries would become more valuable, with distributional effects depending on the specific instruments used (Bento et al., 2006).

\section{Beneficial policy adjustments}

The case of urban land is a good example of how public policy should be adjusted in the presence of ambitious mitigation efforts. It becomes clear that in cities, climate policy should be accompanied by land-based taxes in order to skim off newly created rents. This is especially relevant if climate policy leads to an inefficient overinvestment in land together with an underinvestment in capital.

A further potential synergy between environmental and fiscal policy was identified already by Tullock (1967), who anticipated the debate about 'double dividends' of environmental tax swaps (see Pearce (1991) for an early application to climate policy). A double dividend is typically understood to occur if a new or increased environmental tax also reduces economic distortions induced by the tax system, because its revenues are used to cut other distortionary taxes. This is preferable to lump-sum redistribution of the revenues (Goulder, 1995). However, Bovenberg and De Mooij (1994) highlight an important caveat: the beneficial reduction of the preexisting distortionary taxes ('revenue recycling effect') might be offset by a reduction of real wages since environmental taxes increase product prices ('tax interaction effect'). Thus, the welfare costs of the tax swap without the environmental effect may still be negative (see for example Bovenberg and van der Ploeg (1994), Parry (1995) or Goulder (2013) for more details).

However, a double dividend becomes more likely if certain simplifying assumptions made in that debate are relaxed, and if instead one assumes that:

9 Mitigation-related changes in land use may also affect food prices, which may become a fiscal issue in particular in developing countries in the form of support schemes for the poor. 
a) the tax system before introduction of environmental policy was inefficient (Bento and Jacobsen, 2007; Goulder, 2013; Koskela and Schöb, 2002),

b) environmental quality affects labour supply or the consumption of 'defensive' goods (FitzRoy, 1996; Schwartz and Repetto, 2000),

c) pollution affects macroeconomic production instead of affecting only households' utility (Bovenberg and de Mooij, 1997; Barrage, 2014; Franks et al., 2015).

The 'classic' double-dividend debate mainly considered swaps between ideally implemented taxes in closed economies. More recently, two further cases have been pointed out, in which carbon pricing can replace other, more conventional fiscal policy, to increase overall efficiency of the tax system.

First, Markandya et al. (2013) show that if there is evasion of conventional taxes and a shadow economy, a carbon price makes the tax system more efficient when its revenues are used to reduce labour taxes. Also, Liu (2013) finds that for an environmental tax reform that cuts emissions by $10 \%$, the reductions of tax evasion may lower the overall welfare costs by $28 \%$ in the USA, $89 \%$ in China, and $97 \%$ in India. This effect may thus be a particularly relevant climate-fiscal interaction for many economies in transition and developing countries if carbon pricing can be more effectively enforced than a labour tax (see also Kuralbayeva, 2013).

Second, the analysis of international settings with factor mobility has revealed new potential for a double dividend. ${ }^{10}$ Consider transboundary pollution such as greenhouse gases and assume that capital is mobile. Can decentralized decision-making in setting both capital and carbon taxes be optimal? Eichner and Runkel (2012) find the intuitive result that there is inefficient underprovision of the public good of mitigation due to tax competition and a race-to-the-bottom in capital taxes. ${ }^{11}$ However, when governments use carbon pricing to appropriate resource rents (because a carbon price acts like a tax on rents) and then invest these revenues in infrastructure, they may reduce the fiscal externality of tax competition (Franks et al., 2015). Thus, even if a national government does not take environmental damages into account, it has an incentive to tax carbon instead of capital. ${ }^{12}$ The

10 Several strands of literature have discussed international climate policy extensively. Topics include cooperation and coalition formation, the pollution haven hypothesis, carbon leakage, border tax adjustments as well as the green paradox. However, these topics have not been analyzed as interactions between fiscal policy and climate policy so far, so we do not cover them here.

11 Ogawa and Wildasin (2009) surprisingly find that decentralized decision making leads to an efficient outcome. However, their result critically hinges on the unrealistic assumption that capital supply is fixed. Withagen and Halsema (2013) do assume endogenous capital supply in a model of environmental tax competition, and find a counter-intuitive race-to-the-top in environmental policies. However, the main driver of the inefficiently high environmental taxes is the rather strong assumption that capital and environmental quality are complements.

12 If a national government actually does take into account environmental concerns, the result of Franks et al. (2015) is still valid: The authors show that a unilateral fiscal reform replacing capital with carbon taxes does not cause a green paradox (Sinclair, 1992, 1994; Ulph and Ulph, 1994; Sinn, 2008). In the international Nash equilibrium neither intertemporal, nor international carbon leakage occurs. A carbon tax financed infrastructure spending scheme thus also constitutes a viable green policy. However, distributional concerns remain in the context of unilateral carbon taxes, which may cause jobs in energy-intensive sectors to 
superiority of carbon taxes over capital taxes found by Franks et al. (2015) is due to three underlying effects. First, national carbon taxes are less prone to cause capital flight. This is because capital taxation directly affects the interest rate, and - due to a certain degree of substitutability - carbon taxes affect the interest rate only indirectly. Second, there is a fundamental asymmetry in tax bases. While fossil resources are associated with rents, capital is not. Hence carbon taxes have the advantage of appropriating resource rents. Third, the two previous effects reduce the costs of public funds, thus increasing the optimal level of public revenues (see also Section 2.2). Assuming that public spending on infrastructure increases productivity (Romp and de Haan, 2007), substituting carbon taxes for taxes on capital may counteract the harmful race-to-the-bottom caused by capital mobility.

\section{Implications for very stringent climate policy}

All of the above discussed interactions matter for sound policy making under stringent mitigation targets as called for by the Paris Agreement. Moving from a stringent - "well below" $2^{\circ} \mathrm{C}-$ to a very stringent $-1.5^{\circ} \mathrm{C}-$ target leads to three changes: First, potential revenues from climate policies will increase significantly. As Luderer et al. (2013) show, the potential revenue from carbon taxation over the 21 st century is at least three times higher in a $1.5^{\circ} \mathrm{C}$ scenario compared to a $2^{\circ} \mathrm{C}$ scenario. Second, the case for choosing carbon pricing instruments over technology standards is strengthened: For more ambitious mitigation, the implicit subsidy associated with a technology standard reduces the incentive to abate emissions by reducing output compared to reducing emissions per unit of output (Goulder et al., 2016). Third, the importance of land for reducing emissions via bioenergy and carbon capture and storage (BECCS) increases non-linearly (Luderer et al., 2013), although this mitigation option inevitably means greater competition for land with agricultural production and biodiversity conservation. The value of land rents would thus increase drastically if technological progress in the respective sectors does not compensate for the increased scarcity. ${ }^{13}$ More research is needed to understand the socio-economic implications of such a dramatic increase (Creutzig et al., 2015b), to identify feasible policies for countering urban land rent changes induced by climate policies related to transport and buildings, and to assess the magnitude of the macroeconomic portfolio effect as well as the related implications of stranded assets for the financial sector (Battiston et al. 2017).

\subsection{The role of public spending for mitigation}

Despite the prominent role of carbon pricing in climate policy, there are also important interactions between climate policy and public spending that have recently gained attention. These potentially

relocate abroad. Schwerhoff and Franks (2017) show that governments can mitigate adverse distributional effects on these sectors by implementing sectoral labour tax cuts instead of carbon tax exemptions. For a broader perspective on distributional implications of climate policy, see Section 2.3.

13 In a wider context, it may be enlightening to think through interactions of land use and fiscal policies in the context of protecting the global commons. 
beneficial interactions concern, first, the total level of public spending and second, its composition. For each of these two issues, we again first assess situations in which climate- and spending policies are designed independently (without specific adjustments to contribute to each other's goals). We then turn to reasons for integrating them, and again close with a summary of policy implications and research gaps.

\section{The level of public spending}

In contrast to the previous section, we now consider policy reforms that are explicitly not revenue-neutral. We first consider optimal adjustments to public spending, and then cases in which public spending is restricted and carbon pricing may offer a remedy.

Even without any particular changes to the general rules and practices of public spending, when a consistent climate policy is introduced, an optimal reaction would be to adjust to a new (probably higher) spending level, for two reasons:

First, if the tax system is inefficient, carbon pricing may lower the costs of raising a given total amount of public funds, as discussed in the previous section. Double-dividend studies that analyze swaps between carbon pricing and taxes without imposing revenue neutrality include this effect. ${ }^{14}$ Second, the benefit that can be achieved by a given amount of public spending is likely to be higher when a stringent climate change mitigation target is adopted (see also the discussion of appropriate 'welfare baselines' in Section 3). The reason is that in some high-emission sectors, a transition to low-carbon technologies and demand patterns requires specific public spending. One example are positive externalities of generating knowledge that may cause suboptimal private spending on mitigation-relevant R\&D for renewable energy sources (Fischer and Newell, 2008) or energy efficiency (Gillingham and Palmer, 2014), so that public spending on research grants or subsidies for R\&D activities may be required. ${ }^{15}$ Other examples include adjustments to public infrastructure capital stocks in energy and transport that are required for mitigation (see below), public spending on adaptation to climate change, and potentially on compensations for distributional effects of climate change and mitigation policies (Section 2.3).

Together, this implies that an increase in the total level of public spending is generally welfare-enhancing. The increase in public spending in this new optimum may of course also include spending options that are unrelated to climate change, depending on the marginal benefit of each option. When these contribute to other public sector goals such as employment (Fankhauser et al.,

14 As discussed in Section 2.1, Franks et al. (2015) is an example for this. Goulder (2013) highlights that 'green taxes' should not only be part of optimal tax portfolios: even when starting from a sub-optimal distortionary tax system, additional revenue should come from a higher green tax rather than an 'ordinary' tax, as long as the green tax is 'not too large'.

15 Alternative instruments include patents or environmental policy instruments that 'induce' innovation (Jaffe et al., 2003). 
2008) and economic growth (Popp and Newell, 2012), this may increase the political attractiveness of comprehensive climate policy packages. This however rests on the assumption that such a beneficial expansion of the public budget is possible and politically preferable to a budget-neutral reform.

In contrast, if the total public spending level is restricted to a suboptimally low level, an explicit integration of public spending- and climate policies is beneficial and attractive when carbon pricing revenues can partly alleviate that restriction. In practice, the public budget is not always optimally sized, and it may not be straightforward to increase it even when the marginal costs of public funds fall. Specifically, there is evidence that public capital levels are often too low, in particular in the long run and for core infrastructure in transport and public utilities (Bom and Ligthart, 2014; Calderón et al., 2015). Depending on the inefficiencies behind this, additional revenues from climate policy may offer some remedy. ${ }^{16}$

Several reasons might explain the inadequacy of public capital levels: One reason is that the current allocation of public funds may not maximize net benefits, for example due to 'earmarking' of revenues from earlier tax reforms (Wagner, 1991). It is unclear if this would also apply to additional revenues from very stringent climate policy, or if these could be allocated optimally at least initially. ${ }^{17}$ Moreover, suppose that too high discounting leads to too little long-term investment. In this case, stringent climate policy could hardly alleviate the budget constraint - it would only be feasible if current generations could benefit from future avoided damages in some way (e.g. via increasing asset prices, see Section 3) and would more likely be revenue-neutral, or at least not based on long-term strategies.

Finally, there may be a lack of fiscal tools for financing long-term projects with high upfront costs, e.g. political limits on public debt such as a maximum ratio of total or new debt to GDP. Then, additional revenues from climate policy may indeed offer more flexibility for long-term investments. A conservative political limit on public debt may coincide with political opposition to raising some general tax only to increase spending, but doing so with revenues from a carbon tax may be slightly easier because it is additionally justifiable on environmental grounds.

A related option is to use climate policy revenues for reducing public debt. However, a general negative effect of public debt on the economy is controversial empirically (Woo and Kumar, 2015; Herndon et al., 2013) and to our knowledge not clearly supported by theory. The literature on public debt and climate policy (Carbone et al., 2012; Ramseur et al., 2012; Rausch, 2013) also does not give a

16 According to Jakob et al. (2016), the revenues between 2015 and 2030 from globally harmonized, national carbon prices in line with a $450 \mathrm{ppm} \mathrm{CO}_{2}$ stabilization target would exceed the costs of providing universal access to water, sanitation and electricity. Theoretically, financing public investment by taxing the rents on fixed factors Arnott and Stiglitz (1979) may even establish the socially optimal allocation (Mattauch et al., 2013). This may also hold for a tax on carbon rather than a tax on land with modifications.

17 Burtraw and Sekar (2014) and Klenert et al. (2017) provide data on revenue recycling in current carbon pricing schemes. Esch (2013) discusses earmarking within the EU ETS. Brett and Keen (2000) and Anesi (2006) theoretically analyze the practice of earmarking environmental taxes. 
new argument of why debt would be inefficient. Instead, the additional inefficiency related to public debt is a governmental failure to optimally pay off the debt. This simply combines two effects: debt reduction by carbon pricing can be less costly than by other taxes, and revenue from climate policy can help governments to optimize the intertemporal distribution of debt repayment which affects intergenerational distribution (Section 3).

In sum, if suboptimal public spending is due to earmarking or high discounting, it is unclear if climate policy revenues offer a solution. Improvement potentials are likely to exist if low long-term public investment is due to restricted access to financing instruments.

\section{The composition of infrastructure provision}

Some mitigation-relevant sectors such as electricity and transport are highly dependent on public infrastructure. For these sectors, policies that directly address and change private behaviour, such as carbon pricing or emission standards, should be matched by adjustments to the composition of public spending. These include, most importantly, investment shifts towards infrastructure that complements decentralized renewable electricity generation or low-carbon transport modes. ${ }^{18}$ The basic recommendation of a public investment shift may not be surprising: it even follows from a traditional approach to infrastructure provision that focuses on satisfying demands (such as the classic 'predict and provide' paradigm of transport planning (Goulden et al., 2014)), without mitigation as an explicit aim of public spending. However, one should not jump to the conclusion that this 'division of labour' approach to public investment - some direct measures take care of internalizing climate damages and correcting private transport demands, and infrastructure investment simply reacts - is still appropriate in the context of stringent climate change mitiation. Specifically, it has been criticized on three accounts:

First, it may obscure some relatively low-cost mitigation options. For example, large-scale transport decarbonization strategies often focus on vehicle technologies, neglecting that a different infrastructure could induce overall transport demand reductions and modal shifts (Creutzig et al., 2015a) and even influence preference formation itself (Mattauch et al., 2016a; Mattauch and Hepburn, 2016).

Second, it neglects that policies that redirect only new investments may not be enough, in particular for very ambitious mitigation targets: existing infrastructures and the spatial patterns they support are very long-lived and perpetuate demand patterns and the use of high-carbon technologies far into the future (Shalizi and Lecocq, 2014). Thus, it is likely that a premature retirement of some parts of

${ }^{18}$ Electricity infrastructure with public good characteristics such as power networks and backup generation capacities has often been privatized. Here, a change in the composition of infrastructure capital stocks can be induced by a change in regulation. 
the capital stock will be necessary (Guivarch and Hallegatte, 2011; Waisman et al., 2012; Pfeiffer et al., 2016).

Third, it assumes that demands are indeed fully corrected, for example by a high carbon price. This will very often not be the case, so that the division of labour between climate- and infrastructure policy breaks down. In this second-best case, the composition of infrastructure investments becomes an instrument of climate policy itself, actively shaping private behaviour rather than only satisfying derived demands for infrastructure (Siegmeier, 2015). ${ }^{19}$ If there is a fixed mitigation target, the supply of infrastructure complementary to low-carbon modes of transport and energy production should be increased above the first-best case to make up for the too-low carbon price. Vice versa, if low-carbon infrastructure supply is suboptimally low, the carbon price should be increased above its first-best level to still achieve the mitigation target. ${ }^{20}$

In turn, if not enough infrastructure is supplied to support large-scale low-carbon transport (rails, bicycle tracks, electric vehicle chargers, etc.) and renewable power generation (grid structure, potentially storage- or backup capacities), even a high carbon price will be ineffective and inefficient.

\section{Implications for very stringent climate policy}

In sum, it may be optimal to expand overall public spending in the context of climate policy, and this is even possible for pre-existing spending restrictions that carbon pricing can partly alleviate. The expansion is likely to be stronger with more stringent climate policies, and to the extent that it includes non-mitigation spending, it offers a chance to improve the political feasibility of climate policy compared to revenue-neutral reforms. Moreover, the composition of public spending on different types of transport and energy infrastructure has to be adjusted to match or even to add to the incentives provided by 'direct' mitigation instruments such as carbon-related fuel taxes or electric vehicle subsidies. Since large-scale infrastructure adjustments tend to take decades and even strong direct instruments may be ineffective and costly without them, active infrastructure policies that shape demand and technology patterns should be a top priority in particular in ambitious mitigation programmes with a tight timeline. Vice versa, more research is urgently needed on how to deal with the premature retirement of large and long-lived capital stocks and infrastructure which may become necessary, and on how to harness behavioural changes for emission reductions by specific public spending.

\footnotetext{
19 Active infrastructure policies were also incorporated in 'transport demand management' approaches (Meyer, 1999) in the US and the UK, which however were of limited success to date (Goulden et al., 2014).

20 The results of Waisman et al. (2012), who show that the costs and necessary carbon price for achieving a $2^{\circ} \mathrm{C}$ target can be lowered by ad-hoc adjustments to transport infrastructure and relocations, can be interpreted in this way. For endogenous mitigation, there may be situations in which a restricted carbon price also implies less low-carbon infrastructure, because the utility foregone by providing less dirty infrastructure outweighs gains from environmental quality (Siegmeier, 2015).
} 


\subsection{Distribution}

So far, we have considered interactions of climate policy and public finance at the aggregate level, under the tacit assumption that households are homogeneous. Climate policy, however, also has strong distributional effects, both on the revenue-raising and on the spending side. Apart from normative concerns, this is important for the political feasibility of very stringent climate policy (see also Section 3). First, we summarize the most relevant distributional effects of climate policy; second, we discuss what is known so far about how the recycling of the revenues of carbon pricing influences the distribution; third, we derive policy implications on how to minimize the distributional effects that may otherwise impede ambitious climate policy and summarize research gaps. The main focus of this section lies on the distribution between different households at the same point in time; for distributional effects between current and future generations, see Section 3.

\section{Distributional effects of climate policy}

It is necessary to distinguish between the distributional impacts of a carbon tax on the uses and the sources side. Distributional effects on the uses side appear if climate policy leads to an increase in the prices of more carbon-intensive goods. This increase burdens households differently, due to differences in their consumption patterns. Sources-side effects appear through changes in the relative factor prices of different production inputs, induced by climate policy.

Following Fullerton (2011), there are several reasons why climate policy can make low-income households worse off: The most important uses-side effect is that these households spend a larger portion of their income on carbon-intensive goods (Flues and Thomas, 2015; Grainger and Kolstad, 2010; Levinson and O'Brien, 2015). Climate policy increases the price of these goods and would thus be regressive. This effect, however, does not necessarily occur in developing countries (Sterner, 2011), depending on the use of kerosene and the continued use of biomass as primary fuels. Several empirical studies that estimate the distributional effects of carbon pricing based on expenditure data confirm its regressivity (Hassett et al., 2011; Poterba, 1991; Wier et al., 2005), however Cronin et al. (2017) highlight that considering average tax changes for a specific group of the income distribution hides sizeable heterogeneity within that group.

These studies, however, neglect important general equilibrium effects. Fullerton and Heutel (2007, 2010) demonstrate that the incidence of carbon pricing on the uses side is regressive, while the incidence on the sources side can be regressive, neutral or progressive, depending on the parameters regarding the substitutability between capital, labour and emissions. Rausch et al. (2010) find that under certain circumstances, the progressive impacts of a carbon tax on the sources side exceed the regressive impacts on the uses side, which in sum leads to a mildly progressive effect even without recycling of the revenues in a model calibrated to the U.S. economy. Dissou and Siddiqui (2014) 
confirm that distributional effects on the sources side are likely to be progressive. A prominent example for a regressive effect on the sources side is that unskilled workers might lose their jobs in polluting industries, while newly created jobs for example in the renewable energy sector might require a higher level of education. ${ }^{21}$

\section{Designing equitable climate policy}

There is wide agreement that the recycling of carbon pricing revenue can be designed such that it mitigates or even completely neutralizes the regressive effects of the pricing (Bento et al., 2009; Bento, 2013; Metcalf, 1999; Parry and Williams III, 2010). Two recycling options for the revenue are conceivable: returning the revenue to the taxpayer through tax cuts or transfers, or using the revenue for some form of public investment. Several theoretical contributions have been made regarding the first option: smaller theoretical models with different types of household heterogeneity show that the regressive effect of carbon pricing can be mitigated by recycling the tax revenue progressively. For instance this can be achieved through non-linear labour tax cuts or uniform lump-sum transfers. However, these models disagree on the extent of this effect (Chiroleu-Assouline and Fodha, 2014; Fullerton and Monti, 2013; Klenert and Mattauch, 2016). Larger, calibrated models, such as the model used in Rausch et al. (2011); Williams et al. (2015), lead to the conclusion that the regressive effects of the pricing can be completely neutralized, but that this has efficiency costs. Finally, publications based on optimal taxation theory show that, if the income tax system before the introduction of carbon pricing is inefficient, using the pricing revenue for moving the income tax system closer to its optimum can enhance efficiency, either in a distribution-neutral way (Kaplow, 2012) or even so as to decrease inequality below initial levels (Klenert et al., 2016b).

There is very little literature regarding the second option - the use of carbon pricing revenue for public investment. Since the distributional effects of carbon pricing are immediate but those of public investment occur in the long term, it is hard to analyze them in a joint framework. There is general agreement in the empirical literature that investment in infrastructure can reduce inequality, for example by providing health care and education to poor parts of society (Calderón and Chong, 2004; OECD, 2012). The theoretical literature is ambiguous: In a growth model with heterogeneous dynastic agents, Chatterjee and Turnovsky (2012) show that government spending increases inequality in welfare and wealth in the long run. Glomm and Ravikumar (1994) find that public spending financed

21 Other distributional effects of climate policies are: First, for capital-intensive abatement technologies, environmental policies would drive up the demand for capital. This would depress wages which would have a regressive effect since low-income households receive most of their income from wages. Second, when pollution permits are grandfathered to firms, scarcity rents are created, which again go to the high-income firm owners (Parry, 2004). Third, low-income households may attach a lower value to environmental quality and care more for goods like food and shelter. Thus, high-income households would benefit more from avoided damages. Fourth, avoided damages to capital increase the present value of capital, for example of 
by income taxation is neutral on the income distribution. Mattauch et al. (2016b) and Klenert et al. (2016a) show in a heterogeneous-agent model that public spending in itself has a mildly progressive effect. The net distributional effect, however, is determined by the way the revenue for the spending is raised. It hence is unclear if recycling the carbon tax revenue via public investment in infrastructure has the potential to offset the potential regressive effect of the tax itself.

\section{Implications for very stringent climate policy}

In sum, the distributional effects of climate policy can be regressive when the recycling of the revenue is not taken into account. The more stringent the policy, the more regressive its uses-side effect. It is hence crucial to pair a carbon pricing instrument with some kind of revenue recycling that neutralizes or overcompensates its inequality-increasing effect. Several options fulfill this criterion, such as using the revenue for specific forms of transfers to poor households, uniform lump-sum transfers, or tax cuts. In particular, using the revenue for a progressive reform of the income tax system has the potential to reduce inequality below initial levels - this policy would also enhance efficiency by reducing the cost of labour. Several questions remain critically understudied. For instance, what would be the environmental and distributional effects of financing green infrastructure through a price on carbon? How do land-based mitigation options affect the distribution through food price increases? And what are the distributional impacts of climate policy measures when labour markets are not perfectly competitive due to minimum wages, social security contributions and an informal sector?

\section{Discussion}

The previous section provided a broad range of cases in which climate- and fiscal policies contribute to each other's objectives, or interact so that a closer integration is desirable. However, the body of literature on most of these interactions is still relatively small and recent, except for (and despite) the debate on environmental tax swaps since Tullock (1967). As he already noted, "economists, like everyone else, sometimes keep ideas in watertight compartments. Fiscal policy has normally been dealt with quite separately from the problem of externalities" (ibid, p.643). We now discuss two potential obstacles for further policy integration that may also explain this lack of interest.

On the one hand, mitigation-related and fiscal externalities will only be assessed within one framework if their existence and relevance is acknowledged. However, relevance can be a chicken-and-egg question as some potential welfare improvements only become visible relative to a baseline that is re-evaluated and 'corrected downwards' in the light of multiple inefficiencies. If inefficiencies beyond the basic climate externality are not acknowledged, this may compromise the 
usefulness of some of the arguments in Section 2 in the political process. This will be less of a problem for 'tangible' interactions involving large financial flows, for example from carbon pricing.

On the other hand, there may be a principal objection to an integrated approach, namely the doubt that through the appearance of a 'new' problem to be addressed by policy, addressing existing imperfections becomes any more feasible or actually yields a genuine benefit. This can be rebutted on two grounds:

First, the theory of the second best stresses that, if one externality is not corrected, the optimal allocation on all other markets differs from the first-best allocation (Lipsey and Lancaster, 1956). Some of the effects considered in Section 2 indeed confirm that adjusting policy measures supposed to address distortions independent of climate policy does have beneficial effects when stricter climate policy is introduced. ${ }^{22}$

Second, from a political economy perspective, it is typically more feasible to design tax reforms that combine several public finance measures tailored to win the support of special interest groups (Grossman and Helpman, 2001) and voters (Castanheira et al., 2012). In particular, the government may be constrained by not being able to raise non-environmental, distortionary taxes on political grounds (Section 2.2), even if levying these taxes to increase government spending would increase total productivity. How this matters in political practice seems to be an understudied question, although the succesful introduction of the Swedish carbon tax (Sterner, 1994; Hammar, Sterner, Åkerfeldt, 2013) and the German ecological tax reform (Beuermann and Santarius, 2006) were both explicitly motivated by additional fiscal concerns.

The second point is also particularly relevant because of the intertemporal nature of the climate problem: there are costs for mitigation today, while most benefits from avoided damages occur in the future. This offers an opportunity to design Pareto-improving climate policies to get over the obstacle that mitigation policy can be costly today (Foley, 2008; Broome, 2012): In principle, the net costs of climate policy could be lower at every point in time if mitigation was combined with intergenerational redistribution. This would also separate the solution of the climate problem from the more general (and politically even more difficult) considerations of intergenerational justice (Broome, 2012). Proposed policies to implement the required intergenerational transfer are typically fiscal instruments. Examples from the literature include reduced capital accumulation (Foley, 2008; Rezai et al., 2012), a mechanism based on pay-as-you-go (PAYG) or other pensions between generations (von Below et al.,2013; Dao et al., 2016), and transfers through public debt policy (Bovenberg and Heijdra,1998; Bovenberg and Heijdra, 2002).

effect.

22 Combet (2013) and Combet and Hourcade (2014) defend a view similar to that of this article for the case of interactions of climate policy with the social security system. 
Our review is not exhaustive: Most of the recently analysed interactions that we reviewed here presuppose the traditional perspective of a well-informed, 'monolithic' government and are mediumor long-term effects. Other non-climate inefficiencies which may interact with climate policy can result from inefficiencies in the government's actions and include: informational asymmetries between the government and the private sector, horizontal and vertical externalities of public policies in countries with a federal structure (Keen, 1998), or labour market rigidities (Guivarch et al., 2011). Further, short-term effects reflected in cyclical climate policy or 'Green Keynesianism' is another related field not considered here (Fischer and Heutel, 2013; Harris, 2013).

\section{Conclusion}

This article assesses links between climate change mitigation and other, allegedly conflicting objectives of fiscal policy and their implications for implementing very stringent climate policy, such as that implied by the Paris Agreement's $1.5^{\circ} \mathrm{C}$ warming goal. We find that carefully designed, integrated climate- and fiscal policies in most cases can actually support each other's objectives.

At the beginning of the article, we imagined a challenged policy-maker who is in favour of carbon pricing to solve climate change in principle, but faces resistance to this. What has she learned from our overview of interactions and potential benefits? First, an alignment of objectives may be most apparent for carbon pricing, which can increase the efficiency of the tax system, reduce international tax competition and support efficient capital accumulation. Second, however, the feasibility of a substantial carbon price required for ambitious mitigation hinges on its distributional effects, which in turn strongly depend on the recycling of its revenues within the tax system, by transfers or public spending. Third, other interactions may be less apparent, but no less decisive: effective mitigation requires active transport- and energy infrastructure policies when the carbon price is too low or when societies are locked into existing emission intensive infrastructure. Mitigation-induced changes in urban and agricultural land rents in particular for ambitious mitigation pathways imply that land-based taxes should also be integrated into climate policy packages.

On the other hand we find that although the revenues generated by stringent climate policy could make up a significant share of governments' budgets, the magnitudes of many of the novel interaction effects reviewed in this article, or policies to exploit or counter them, are still under-researched. So far, climate policy assessments have predominantly focused on technological options, neglecting many interactions with public finance with the exception of tax swaps. The current debate about the $1.5^{\circ} \mathrm{C}$ target again focuses on technological feasibility - but ensuring its political feasibility requires that the large fiscal flows and distributional effects induced by correspondingly stringent policy instruments are also anticipated and exploited. Providing 
policymakers with the economic arguments why climate policy can benefit economic prosperity even beyond avoided climate damages is, we believe, vital for very ambitious mitigation.

\section{References}

Anesi, V., 2006. Earmarked taxation and political competition. Journal of Public Economics 90(4-5), 679-701.

Arnott, R. J., Stiglitz, J. E., 1979. Aggregate land rents, expenditure on public goods, and optimal city size. Quarterly Journal of Economics 93(4), 471-500.

Barrage, L., 2014. Optimal dynamic carbon taxes in a climate-economy model with distortionary fiscal policy. Working paper.

Battiston, S., Mandel, A., Monasterolo, I., Schutze, F., Visentin, G., 2017. A climate stress-test of the financial system (including supplementary information). Nature Climate Change 7, 283-288.

Bento, A. M., 2013. Equity impacts of environmental policy. Annual Review of Resource Economics 5, 181-196.

Bento, A. M., Franco, S. F., Kaffine, D., 2006. The efficiency and distributional impacts of alternative anti-sprawl policies. Journal of Urban Economics 59(1), 121-141.

Bento, A. M., Goulder, L. H., Jacobsen, M. R., von Haefen, R. H., 2009. Distributional and efficiency impacts of increased US gasoline taxes. American Economic Review 99(3), 667-699.

Bento, A. M., Jacobsen, M., 2007. Ricardian rents, environmental policy and the 'double-dividend' hypothesis. Journal of Environmental Economics and Management 53(1), 17-31.

Beuermann, C., Santarius, T., 2006. Ecological tax reform in Germany: handling two hot potatoes at the same time." Energy Policy 34(8):917-929.

Bom, P. R., Ligthart, J. E., 2014. What have we learned from three decades of research on the productivity of public capital? Journal of Economic Surveys 28(5), 889-916.

Bovenberg, A., Heijdra, B. J., 1998. Environmental tax policy and intergenerational distribution. Journal of Public Economics 67(1), 1-24.

Bovenberg, A. L., De Mooij, R. A., 1994. Environmental levies and distortionary taxation. The American Economic Review 84(4), 1085-1089.

Bovenberg, A. L., de Mooij, R. A., 1997. Environmental tax reform and endogenous growth. Journal of Public Economics 63(2), 207-237.

Bovenberg, A. L., Heijdra, B. J., 2002. Environmental abatement and intergenerational distribution. Environmental and Resource Economics 23(1), 45-84.

Bovenberg, A. L., van der Ploeg, F., 1994. Environmental policy, public finance and the labour market in a second-best world. Journal of Public Economics 55(3), 349-390.

Bowen, A., 2011. Raising climate finance to support developing country action: some economic considerations. Climate Policy 11(3), 1020-1036.

Brett, C., Keen, M., 2000. Political uncertainty and the earmarking of environmental taxes. Journal of Public Economics 75(3), 315-340.

Broome, J., 2012. Climate matters. Ethics in a warming world. W.W. Norton \& Company, New York.

Burtraw, D., Sekar, S., 2014. Two world views on carbon revenues. Journal of Environmental Studies and Sciences 4(1), 110-120.

Calderón, C., Chong, A., 2004. Volume and quality of infrastructure and the distribution of income: An empirical investigation. Review of Income and Wealth 50(1), 87-106.

Calderón, C., Moral-Benito, E., Servén, L., 2015. Is infrastructure capital productive? a dynamic heterogeneous approach. Journal of Applied Econometrics 30(2), 177-198.

Carbone, J. C., Morgenstern, R. D., Williams III, R. C., 2012. Carbon taxes and deficit reduction. Working paper. 
Castanheira, M., Nicodème, G., Profeta, P., 2012. On the political economics of tax reforms: survey and empirical assessment. International Tax and Public Finance 19(4), 598-624.

Chatterjee, S., Turnovsky, S. J., 2012. Infrastructure and inequality. European Economic Review 56(8), 1730-1745.

Chiroleu-Assouline, M., Fodha, M., 2014. From regressive pollution taxes to progressive environmental tax reforms. European Economic Review 69, 126 - 142.

Clarke, L., Jiang, K., Akimoto, K., Babiker, M., Blanford, G., Fisher-Vanden, K., Hourcade, J.-C., Krey, V., Kriegler, E., Löschel, A., McCollum, D., Paltsev, S., Rose, S., Shukla, P. R., Tavoni, M., van der Zwaan, B., van Vuuren, D., 2014. Assessing transformation pathways. In: Edenhofer, O., Pichs-Madruga, R., Sokona, Y., Farahani, E., Kadner, S., Seyboth, K., Adler, A., Baum, I., Brunner, S., Eickemeier, P., Kriemann, B., Savolainen, J., Schlömer, S., von Stechow, C., Zwickel, T., Minx, J.-C. (Eds.), Climate Change 2014: Mitigation of Climate Change. Contribution of Working Group III to the Fifth Assessment Report of the Intergovernmental Panel on Climate Change, Cambridge University Press.

Combet, E., 2013. Carbon taxation and social progress. Global Union Research Network Discussion Paper No.17.

Combet, E., Hourcade, J.-C., 2014. Taxe carbone, retraites et déficits publics: le coût caché du cloisonnement des expertises. Revue d'économie politique 124, 291-416.

Creutzig, F., Jochem, P., Edelenbosch, O. Y., Mattauch, L., van Vuuren, D. P., McCollum, D., Minx, J., $2015 a$. Transport: A roadblock to climate change mitigation? Science 350(6263), 911-912.

Creutzig, F., Ravindranath, N. H., Berndes, G., Bolwig, S., Bright, R., Cherubini, F., Chum, H., Corbera, E., Delucchi, M., Faaij, A., Fargione, J., Haberl, H., Heath, G., Lucon, O., Plevin, R., Popp, A., Robledo-Abad, C., Rose, S., Smith, P., Stromman, A., Suh, S., Masera, O., 2015b. Bioenergy and climate change mitigation: an assessment. GCB Bioenergy 7(5), 916-944.

Cronin, J. A., Fullerton, D., Sexton, S. E., 2017. Vertical and Horizontal Redistributions from a Carbon Tax and Rebate. NBER Working Paper No. 23250.

Dao, T. N., Burghaus, K., Edenhofer, O., 2016. Self-enforcing intergenerational social contract as a source of pareto improvement and emission mitigation. CESifo Working Paper No. 5896.

de Mooij, R. A., Keen, M., Parry, I. W. H., 2012. Fiscal Policy to Mitigate Climate Change: A Guide for Policymakers. IMF eLibrary, USA.

Dissou, Y., Siddiqui, M. S., 2014. Can carbon taxes be progressive? Energy Economics 42, 88-100.

Edenhofer, O., Jakob, M., Creutzig, F., Flachsland, C., Fuss, S., Kowarsch, M., Lessmann, K., Mattauch, L., Siegmeier, J., Steckel, J. C., 2015a. Closing the emission price gap. Global Environmental Change 31, $132-143$.

Edenhofer, O., Mattauch, L., Siegmeier, J., 2015b. Hypergeorgism: When Rent Taxation is Socially Optimal. FinanzArchiv/Public Finance Analysis 71(4), 474-505.

Eichner, T., Runkel, M., 2012. Interjurisdictional spillovers, decentralized policymaking, and the elasticity of capital supply. American Economic Review 102(5), 2349-57.

Esch, A., 2013. Using EU ETS auctioning revenues for climate action: what is the appetite for earmarking within specific EU member states? Germanwatch Briefing Paper.

Fankhauser, S., Sehlleier, F., Stern, N., 2008. Climate change, innovation and jobs. Climate Policy 8(4), 421-429.

Feldstein, M. S., 1977. The surprising incidence of a tax on pure rent: A new answer to an old question. Journal of Political Economy 85(2), 349-360.

Fischer, C., Heutel, G., 2013. Environmental macroeconomics: Environmental policy, business cycles, and directed technical change. Annual Review of Resource Economics 5, 197-210.

Fischer, C., Newell, R. G., 2008. Environmental and technology policies for climate mitigation. Journal of Environmental Economics and Management 55(2), 142-162.

FitzRoy, F., 1996. Environmental taxes, non-separable externalitities and real wages. Working paper, University of St. Andrews.

Flues, F., Thomas, A., 2015. The Distributional Effects of Energy Taxes: Preliminary Report. OECD Taxation Working Papers 23. 
Foley, D. K., 2008. The economic fundamentals of global warming. In: Harris, J. M., Goodwin, N. R. (Eds.), Twenty-First Century Macroeconomics: Responding to the Climate Challenge, Edward Elgar Publishing, Northampton.

Franks, M., Edenhofer, O., Lessmann, K., 2015. Why Finance Ministers Favor Carbon Taxes, Even if They Do Not Take Climate Change into Account. Environmental and Resource Economics, doi:10.1007/s10640-015-9982-1.

Fullerton, D., 2011. Six distributional effects of environmental policy: Six distributional effects of environmental policy. Risk Analysis 31(6), 923-929.

Fullerton, D., Heutel, G., 2007. The general equilibrium incidence of environmental taxes. Journal of Public Economics 91, 571-591.

Fullerton, D., Heutel, G., 2010. Analytical General Equilibrium Effects of Energy Policy on Output and Factor Prices. The B.E. Journal of Economic Analysis \& Policy 10(2).

Fullerton, D., Monti, H., 2013. Can pollution tax rebates protect low-wage earners? Journal of Environmental Economics and Management 66(3), 539-553.

Gillingham, K., Newell, R. G., Palmer, K., 2009. Energy efficiency economics and policy. Annual Review of Resource Economics 1(1), 597-619.

Gillingham, K., Palmer, K., 2014. Bridging the Energy Efficiency Gap: Policy Insights from Economic Theory and Empirical Evidence. Review of Environmental Economics and Policy 8(1), 18-38.

Glomm, G., Ravikumar, B., 1994. Growth-inequality trade-offs in a model with public sector R\&D. The Canadian Journal of Economics / Revue canadienne d'Economique 27(2), 484-493.

Goulden, M., Ryley, T., Dingwall, R., 2014. Beyond 'predict and provide': UK transport, the growth paradigm and climate change. Transport Policy 32, 139-147.

Goulder, L. H., 1995. Environmental taxation and the double dividend: a reader's guide. International Tax and Public Finance 2(2), 157-183.

Goulder, L. H., 2013. Climate change policy's interactions with the tax system. Energy Economics 40, S3-S11.

Goulder, L. H., Hafstead, M. A. C., Williams, I., Roberton C., 2016. General equilibrium impacts of a federal clean energy standard. American Economic Journal: Economic Policy 8(2), 186-218.

Grainger, C. A., Kolstad, C. D., 2010. Who Pays a Price on Carbon? Environmental and Resource Economics 46, 359-376.

Grossman, G. M., Helpman, E., 2001. Special interest politics. MIT Press.

Guivarch, C., Crassous, R., Sassi, O., Hallegatte, S., 2011. The costs of climate policies in a second best world with labour market imperfections. Climate Policy 11(1), 768-788.

Guivarch, C., Hallegatte, S., 2011. Existing infrastructure and the $2 \hat{A}^{\circ} \mathrm{c}$ target: A letter. Climatic Change 109(3-4), 801-805.

Hammar, H., Sterner, T., Åkerfeldt, S., 2013. Sweden's CO2 tax and taxation reform experiences. In: Genevey, R.; Pachauri, R.; Tubiana, L. (eds.), Reducing Inequalities: A Sustainable Development Challenge. Iddri.

Harris, J. M., 2013. Green Keynesianism: Beyond standard growth paradigms. Working Paper 13-02, Global Development and Environment Institute, Tufts University.

Hassett, K. A., Mathur, A., Metcalf, G. E., 2011. The consumer burden of a carbon tax on gasoline. In: Sterner, T. (Ed.), Fuel Taxes and the Poor: The Distributional Effects of Gasoline Taxation and Their Implications for Climate Policy, Resources for the Future Press. Available at: https://ssrn.com/abstract=2212939.

Herndon, T., Ash, M., Pollin, R., 2013. Does high public debt consistently stifle economic growth? A critique of Reinhart and Rogoff. Cambridge Journal of Economics 38(2), 257-279.

Hertel, T., 2011. The global supply and demand for agricultural land in 2050: A perfect storm in the making? American Journal of Agricultural Economics 93, 259-275.

Jaffe, A. B., Newell, R. G., Stavins, R. N., 2003. Technological change and the environment. In: MÃßler, K.-G., Vincent, J. R. (Eds.), Handbook of Environmental Economics, volume 1, pp. 461-516, Elsevier, 1st edition. 
Jakob, M., Chen, C., Fuss, S., Marxen, A., Rao, N. D., Edenhofer, O., 2016. Using carbon pricing revenues to finance infrastructure access. World Development 84, 254-265.

Jones, B., Keen, M., Strand, J., 2013. Fiscal implications of climate change. International Tax and Public Finance 20(1), 29-70.

Kalkuhl, M., Edenhofer, O., Lessmann, K., 2011. Learning or lockin: optimal technology policies to support mitigation. Resource and Energy Economics 34, 1-23.

Kalkuhl, M., Edenhofer, O., Lessmann, K., 2013. Renewable energy subsidies: Second-best policy or fatal aberration for mitigation? Resource and Energy Economics 35(3), 217-234.

Kaplow, L., 2012. Optimal control of externalities in the presence of income taxation. International Economic Review 53(2), 487-509.

Keen, M., 1998. Vertical tax externalities in the theory of fiscal federalim. IMF Economic Review 45(3), 454-485.

Klenert, D., Mattauch, L., Combet, E., Edenhofer, O., Hepburn, C., Rafaty, R., Stern, N., 2017. Making carbon pricing work. Under review.

Klenert, D., Mattauch, L., 2016. How to make a carbon tax reform progressive: The role of subsistence consumption. Economics Letters 138, 100-103.

Klenert, D., Mattauch, L., Edenhofer, O., Lessmann, K., 2016a. Infrastructure and inequality: Insights from incorporating key economic facts about household heterogeneity. Macroeconomic Dynamics, doi:10.1017/S1365100516000432.

Klenert, D., Schwerhoff, G., Edenhofer, O., Mattauch, L., 2016b. Environmental taxation, inequality and Engel's law: The double dividend of redistribution. Environmental and Resource Economics, doi:10.1007/s10640-016-0070-y.

Koskela, E., Schöb, R., 2002. Optimal factor income taxation in the presence of unemployment. Journal of Public Economic Theory 4(3), 387-404.

Kriegler, E., Tavoni, M., Riahi, K., Van Vuuren, D. P., 2013. Introducing the Limits Special Issue. Climate Change Economics 04(04), 1302002.

Levinson, A., O’Brien, J., 2015. Environmental Engel Curves. NBER Working Paper Series 20914.

LIMITS consortium, 2013. LIMITS database. https://tntcat.iiasa.ac.at/LIMITSPUBLICDB/,retrieved 2017-03-28.

Lipsey, R., Lancaster, K., 1956. The general theory of second best. The Review of Economic Studies 24(1), 11-32.

Liu, A. A., 2013. Tax evasion and optimal environmental taxes. Journal of Environmental Economics and Management 66(3), 656-670.

Luderer, G., Bosetti, V., Jakob, M., Leimbach, M., Steckel, J. C., Waisman, H., Edenhofer, O., 2012. The economics of decarbonizing the energy system - results and insights from the RECIPE model intercomparison. Climatic Change 114(1), 9-37.

Luderer, G., Pietzcker, R. C., Bertram, C., Kriegler, E., Meinshausen, M., Edenhofer, O., 2013. Economic mitigation challenges: how further delay closes the door for achieving climate targets. Environmental Research Letters 8(3), 1-8.

Markandya, A., González-Eguino, M., Escapa, M., 2013. From shadow to green: Linking environmental fiscal reforms and the informal economy. Energy Economics 40, Supplement 1, S108 - S118, supplement Issue: Fifth Atlantic Workshop in Energy and Environmental Economics.

Mattauch, L., Creuzig, F., Edenhofer, O., 2015. Avoiding carbon lock-in: Policy options for advancing structural change. Economic Modelling 50, 49-63.

Mattauch, L., Edenhofer, O., Klenert, D., Bénard, S., 2016a. Distributional effects of public investment when wealth and classes are back. Metroeconomica 67(3), 603-629.

Mattauch, L., Ridgway, M., Creutzig, F. 2016b. Happy or liberal? Making sense of behavior in transport policy design. Transportation Research Part D: Transport and Environment, 45,64-83.

Mattauch, L., Hepburn, C., 2016. Climate policy when preferences are endogenous - and sometimes they are. Midwest Studies In Philosophy 40(1), 76-95. 
Mattauch, L., Siegmeier, J., Edenhofer, O., Creutzig, F., 2013. Financing public capital through rent taxation. CESifo Working Paper No. 4280.

Metcalf, G. E., 1999. A distributional analysis of green tax reforms. National Tax Journal 52(4), 655-681.

Meyer, M. D., 1999. Demand management as an element of transportation policy: using carrots and sticks to influence travel behavior. Transportation Research Part A: Policy and Practice 33(7-8), 575 - 599.

Nordhaus, W. D., Boyer, J., 2000. Warming the World: Economic Models of Global Warming. MIT Press, Cambride, MA and London, UK.

OECD, 2012. Ch.5: Reducing income inequality while boosting economic growth: Can it be done? In: Economic Policy Reforms 2012: Going for Growth, OECD Publishing.

Ogawa, H., Wildasin, D. E., 2009. Think Locally, Act Locally: Spillovers, Spillbacks, and Efficient Decentralized Policymaking. American Economic Review 99(4), 1206-1217.

Parry, I. W., 1995. Pollution taxes and revenue recycling. Journal of Environmental Economics and Management 29, S64-S77.

Parry, I. W., Williams III, R. C., 2010. What are the costs of meeting distributional objectives for climate policy? The BE Journal of Economic Analysis \& Policy 10(2).

Parry, I. W. H., 2004. Are emissions permits regressive? Journal of Environmental Economics and Management 47(2), 364-387.

Pearce, D., 1991. The role of carbon taxes in adjusting to global warming. The Economic Journal 101(407), 938-948.

Pfeiffer, A., R. Millar, C. Hepburn and E. Beinhocker, 2016. The ' $2{ }^{\circ} \mathrm{C}$ capital stock' for electricity generation: Committed cumulative carbon emissions from the power sector and the transition to a green economy. Applied Energy 179, 1395-1408.

Popp, D., Newell, R., 2012. Where does energy R\&D come from? Examining crowding out from energy R\&D. Energy Economics 34(4), 980-991.

Poterba, J. M., 1991. Is the Gasoline Tax Regressive? In: Bradford, D. (Ed.), Tax Policy and the Economy, Vol. 5, pp. 145-164, The MIT Press.

Poterba, J. M., 1993. Global warming policy: a public finance perspective. The Journal of Economic Perspectives $7(4), 47-63$.

Ramseur, J. L., Leggett, J. A., Sherlock, M. F., 2012. Carbon tax: Deficit reduction and other considerations. Congressional Research Service, report.

Rausch, S., 2013. Fiscal consolidation and climate policy: An overlapping generations perspective. Energy Economics 40, S134-S148.

Rausch, S., Metcalf, G. E., Reilly, J. M., 2011. Distributional impacts of carbon pricing: A general equilibrium approach with micro-data for households. Energy Economics 33, S20-S33.

Rausch, S., Metcalf, G. E., Reilly, J. M., Paltsev, S., 2010. Distributional implications of alternative US greenhouse gas control measures. The BE Journal of Economic Analysis \& Policy 10(2).

Rezai, A., Foley, D. K., Taylor, L., 2012. Global warming and economic externalities. Economic Theory 49, 329-531.

Rogelj, J., Luderer, G., Pietzcker, R. C., Kriegler, E., Schaeffer, M., Krey, V., Riahi, K., 2015. Energy system transformations for limiting end-of-century warming to below $1.5 \hat{A}^{\circ} \mathrm{C}$. Nature Climate Change 5(6), 519-527.

Romp, W., De Haan, J., 2007. Public capital and economic growth: A critical survey. Perspektiven der Wirtschaftspolitik 8(S1), 6-52.

Schwartz, J., Repetto, R., 2000. Nonseparable utility and the double dividend debate: Reconsidering the tax-interaction effect. Environmental and Resource Economics 15(2), 149-157.

Schwerhoff, G. and M. Franks, 2017. Optimal Environmental Taxation with Capital Mobility. Fiscal Studies, forthcoming. 
Seto, K., Dhakal, S., Bigio, A., Blanco, H., Delgado, G., Dewar, D., Huang, L., Inaba, A., Kansal, A., Lwasa, S., McMahon, J., Müller, D., Murakami, J., Nagendra, H., Ramaswami, A., 2014. Human settlements, infrastructure and spatial planning. In: Edenhofer, O., Pichs-Madruga, R., Sokona, Y., Seyboth, K., Matschoss, P., Kadner, S., Zwickel, T., Eickemeier, P., Hansen, G., Schloemer, S., von Stechow, C. (Eds.), Climate Change 2014: Mitigation of Climate Change. Contribution of Working Group III to the Fifth Assessment Report of the Intergovernmental Panel on Climate Change, Cambridge University Press, Cambridge, United Kingdom and New York, NY, USA.

Shalizi, Z., Lecocq, F., 2014. The economics of targeted mitigation in infrastructure. Climate Policy 14, 187-208.

Siegmeier, J., 2015. Keeping Pigou on tracks: second-best carbon pricing and infrastructure provision. MPRA Paper No. 69046.

Siegmeier, J., Mattauch, L., Edenhofer, O., 2015. Climate policy enhances efficiency: A macroeconomic portfolio effect. CESifo Working Paper No. 5161.

Sims, R., Schaeffer, R., Creutzig, F., Cruz-Núñez, X., D'Agosto, M., Dimitriu, D., Figuera Mez, M., Fulton, L., Kobayashi, S., Lah, O., McKinnon, A., Newman, P. and Ouyang, M., Schauer, J., Sperling, D., Tiwari, G., 2014. Transport. In: Edenhofer, O., Pichs-Madruga, R., Sokona, Y., Seyboth, K., Matschoss, P., Kadner, S., Zwickel, T., Eickemeier, P., Hansen, G., Schloemer, S., von Stechow, C. (Eds.), Climate Change 2014: Mitigation of Climate Change. Contribution of Working Group III to the Fifth Assessment Report of the Intergovernmental Panel on Climate Change, Cambridge University Press, Cambridge, United Kingdom and New York, NY, USA.

Sinclair, P.J.N., 1992. High does nothing and rising is worse: carbon taxes should keep falling to cut harmful emissions. The Manchester School 60, 41-52.

Sinclair, P.J.N., 1994. On the optimum trend of fossil fuel taxation. Oxford Economic Papers 46, 869-877.

Sinn, H. W., 2008. Public policies against global warming: a supply side approach. International Tax and Public Finance 15(4), 360-394.

Sorrell, S., Sijm, J., 2003. Carbon trading in the policy mix. Oxford Review of Economic Policy 19(3), $420-437$.

Sterner, T., 1994. Environmental tax reform: the Swedish experience. Environmental Policy and Governance, 4(6), 20-25.

Sterner, T., 2011. Fuel Taxes and the Poor: The Distributional Effects of Gasoline Taxation and Their Implications for Climate Policy. Johns Hopkins University Press.

Thompson, T. M., Rausch, S., Saari, R. K., Selin, N. E., 2014. A systems approach to evaluating the air quality co-benefits of US carbon policies. Nature Climate Change 4, 917-923.

Tullock, G., 1967. Excess benefit. Water Resources Research 3(2), 643-644.

Ulph, A. and D. Ulph, 1994. The Optimal Time Path of a Carbon Tax. Oxford Economic Papers 46, 857-868.

von Below, D., Dennig, F., Jaakkola, N., 2013. Consuming more and polluting less today: Intergenerationally efficient climate policy. Mimeo.

Wagner, R. E. (Ed.), 1991. Charging for Government: User Charges and Earmarked Taxes in Principle and Practice. Routledge, London.

Waisman, H., Guivarch, C., Grazi, F., Hourcade, J. C., 2012. The Imaclim-R model: infrastructures, technical inertia and the costs of low carbon futures under imperfect foresight. Climatic Change 114(1), 101-120.

WDI, 2016. World Development Indicators 2016. The World Bank.

Weyant, J., Davidson, O., Dowlabathi, H., Edmonds, J., Grubb, M., Parson, E., Richels, R., Rotmans, J., Shukla, P., Tol, R., Cline, W., Fankhauser, S., 1996. Integrated assessment of climate change: An overview and comparison of approaches and results. In: Bruce, J., Lee, H., Haites, E. (Eds.), Climate Change 1995: Economic and Social Dimensions of Climate Change, pp. 367-439, Cambridge University Press.

Wier, M., Birr-Pedersen, K., Jacobsen, H. K., Klok, J., 2005. Are $\mathrm{CO}_{2}$ taxes regressive? Evidence from the Danish experience. Ecological Economics 52(2), 239-251.

Williams, R. C. I., Gordon, H., Burtraw, D., Carbone, J. C., Morgenstern, R. D., 2015. The Initial Incidence of a Carbon Tax across US States. National Tax Journal 68(1), 195-214. 
Withagen, C., Halsema, A., 2013. Tax competition leading to strict environmental policy. International Tax and Public Finance 20(3), 434-449.

Woo, J., Kumar, M. S., 2015. Public debt and growth. Economica 82(328), 705-739. 